\title{
Changes in PEP Carboxylase, Rubisco and Rubisco activase mRNA levels from maize (Zea mays) exposed to a chronic ozone stress
}

\author{
LOUIS LEITAO ${ }^{1}$, JEAN-JOSÉ MAORET ${ }^{2}$ and JEAN-PHILIPPE BIOLLEY ${ }^{1, *}$
}

\author{
${ }^{1}$ Laboratoire d'Ecologie Moléculaire, E.A. 3525, I.B.E.A.S., Université de Pau et des Pays de l'Adour, \\ Avenue de 1'Université, BP 1155, F-64013 Pau Cedex, France \\ ${ }^{2}$ INSERM, IFR 31, CHU Rangueil, F-31403 Toulouse Cedex 4, France
}

\begin{abstract}
We quantified the ozone impact on levels of Zea mays L.cv. Chambord mRNAs encoding $\mathrm{C}_{4}$-phosphoenolpyruvate carboxylase $\left(\mathrm{C}_{4}\right.$-PEPc), ribulose-1,5-bisphosphate carboxylase/oxygenase small and large subunits (Rubisco-SSU and Rubisco-LSU, respectively) and Rubisco activase (RCA) using real-time RT-PCR. Foliar pigment content, PEPc and Rubisco protein amounts were simultaneously determined. Two experiments were performed to study the ozone response of the $5^{\text {th }}$ and the $10^{\text {th }}$ leaf. For each experiment, three ozone concentrations were tested in open-top chambers: non-filtered air (NF, control) and non-filtered air containing $40(+40)$ and $80 \mathrm{~nL} \mathrm{~L}^{-1}(+80)$ ozone. Regarding the $5^{\text {th }}$ leaf, +40 atmosphere induced a loss in pigmentation, PEPc and Rubisco activase mRNAs. However, it was unable to notably depress carboxylase protein amounts and mRNAs encoding Rubisco. Except for Rubisco mRNAs, all other measured parameters from $5^{\text {th }}$ leaf were depressed by +80 atmosphere. Regarding the $10^{\text {th }}$ leaf, +40 atmosphere increased photosynthetic pigments and transcripts encoding Rubisco and Rubisco activase. Rubisco and PEPc protein amounts were not drastically changed, even if they tended to be increased. Level of $\mathrm{C}_{4}$-PEPc mRNA remained almost stable. In response to +80 atmosphere, pigments and transcripts encoding PEPc were notably decreased. Rubisco and PEPc protein amounts also declined to a lesser extent. Conversely, the level of transcripts encoding both Rubisco subunits and Rubisco activase that were not consistently disturbed tended to be slightly augmented. So, the present study suggests that maize leaves can respond differentially to a similar ozone stress.
\end{abstract}

Key terms: carboxylase; maize; mRNA; ozone; Rubisco activase

\section{INTRODUCTION}

Nowadays, ozone $\left(\mathrm{O}_{3}\right)$ is recognized as the most phytotoxic and worrying common air pollutant. It is a secondary pollutant formed in the troposphere by the interaction of hydrocarbons, nitrogen oxides and sunlight (Cicerone, 1987; Thompson, 1992). Ozone, that enters the leaf through stomata, can severely affect the survival and yield of plants (Pell et al., 1997; Kolb and Matyssek, 2001). If acute stress from exposure to high concentrations of $\mathrm{O}_{3}$ for short periods of time generally produces visible injury, chronic $\mathrm{O}_{3}$ stress, resulting from exposure to low concentrations for a long period, produces few symptoms of damage and reduces growth (Heath and

\footnotetext{
ABBREVIATIONS USED: AOS, active oxygen species; AOT40, accumulated exposure over a threshold of $40 \mathrm{~nL} \mathrm{~L}^{-1}$ ozone; Car, carotenoid; Chl, chlorophyll; cDNA, complementary deoxyribonucleic acid; DAE, day after emergence; mRNA, messenger ribonucleic acid; NF, non-filtered air; OTC, open-top chamber; PEPc, phosphoenolpyruvate carboxylase; RT-PCR, reverse transcription polymerase chain reaction; Rubisco, ribulose-1,5-bisphosphate carboxylase/ oxygenase; Rubisco-SSU, Rubisco small subunit; Rubisco-LSU, Rubisco large subunit; RCA, ribulose-1,5-bisphosphate carboxylase/oxygenase activase; RuBP, ribulose-1,5-bisphosphate; $+40,+80$, chambered non-filtered air supplied with 40 and $80 \mathrm{~nL} \mathrm{~L}^{-1}$ ozone, respectively.
}

Author for correspondence: Jean-Philippe BIOLLEY, Tel.: +33-(0)5-59-40-74-73, Fax: +33-(0)5-59-40-74-94, E-mail address: jean-philippe.biolley@univ-pau.fr 
Taylor, 1997). Several studies have tried to elucidate the biochemical and molecular mechanisms of ozone toxicity. In short, it is admitted that ozone effects are generated by an excess of AOS which can react with membrane lipids, proteins and DNA resulting mainly in a reduced photosynthesis and an accelerated cell senescence (Pell et al., 1997).

In maize (Zea mays L.), photosynthesis is performed following a $\mathrm{C}_{4}$ pathway which is a complex combination of both biochemical and morphological specialisation able to induce an increase in the $\mathrm{CO}_{2}$ concentration at the site of Rubisco (EC 4.1.1.39) (Von Caemmerer and Furbank, 2003). The secondary autotrophic carboxylation reaction, catalysed by Rubisco, is compartmentalized within the bundle sheath cells and is dependent, for its supply of $\mathrm{CO}_{2}$, on the primary carboxylation reaction, catalysed by PEPc (EC 4.1.1.31) in the cytosol of mesophyll cells (Häusler et al., 2002). Rubisco activity is regulated by Rubisco activase which activates Rubisco in vivo from an inactive complex by restoring the active Rubisco structure (see Portis (2003) for review).

If literature related to the ozone impact on $\mathrm{C}_{3}$ species is very abundant, studies devoted to the response of $\mathrm{C}_{4}$ plants to ozone are particularly rare. Only two papers compared photosynthesis and yield responses of $\mathrm{C}_{3}$ and $\mathrm{C}_{4}$ plants to ozone (Heagle et al., 1988; Miller, 1988). Results from these studies tended to show that $\mathrm{C}_{4}$ plants were more ozone-tolerant than $\mathrm{C}_{3}$ plants. Although the ozone-induced impairment of $\mathrm{C}_{3}$ photosynthesis can be variously explained (Matyssek et al., 1997; Guidi et al., 2000; Dizengremel, 2001; Calatayud and Barreno, 2004), it is acknowledged that Rubisco is a central target for adverse ozone effects. On this subject, several experiments showed that appropriate ozone doses are able to reduce Rubisco quantity and to modify the enzyme structure by introducing carbonyl groups (Eckardt and Pell, 1995; Junqua et al., 2000; Dizengremel, 2001; Kanoun et al., 2002; Leitao et al., 2003). Assuming that the impact of additional carbonyl groups on Rubisco activity established in vitro
(Eckardt and Pell, 1995) is not yet quantified in vivo, and that the impact of ozone on Rubisco activase remains unknown, the ozone-induced decline in Rubisco activity is generally regarded as a consequence of a loss in Rubisco protein content (Pell et al., 1994; Dizengremel, 2001; Pelloux et al., 2001). In $C_{3}$ trees, this ozone-induced decline in Rubisco activity can be accompanied by a spectacular increase in the PEPc activity which reflects a significant stimulation of anaplerotic PEPc protein content (Dizengremel, 2001). Such an increase in PEPc activity probably enhances anaplerotic processes which might be efficient at promoting detoxification and repair of ozone injury by supplying reducing power and skeletons (Dizengremel, 2001). At the molecular level, in $\mathrm{C}_{3}$ species, a few studies tried to quantify ozone-induced variations of mRNA encoding PEPc and the two subunits constitutive of Rubisco. Using Northern blot and densitometric analyses of RT-PCR products, the authors showed that ozone was able to increase PEPc mRNA levels in pine, poplar, Norway spruce, and beech whereas it reduced Rubisco subunit mRNA levels in poplar, pine and potato (Eckardt and Pell, 1994; Pell et al., 1994; Glick et al., 1995; Brendley and Pell, 1998; Pelloux et al., 2001). Regarding $C_{4}$ species, only one study based on the same techniques, reported that maize mRNA encoding Rubisco small subunit was decreased by massive ozone doses (Ruzsa et al., 1999). To our knowledge, there are currently no other data describing the effect of ozone on photosynthetic PEPc and Rubisco involved in the Hatch and Slack pathway.

To gain new insights into the effect of air pollution on $\mathrm{C}_{4}$ plants, we aimed to detect and to quantify a possible ozone impact on the accumulation of some transcripts encoding key enzymes which control the photosynthetic carboxylation activities of Zea mays L. For this purpose, we developed a real-time RT-PCR method able to quantify levels of mRNAs encoding $\mathrm{C}_{4}$-phosphoenolpyruvate carboxylase (PEPc), ribulose-1,5-bisphosphate carboxylase/oxygenase small subunit (Rubisco-SSU), Rubisco large subunit 
(Rubisco-LSU) and Rubisco activase (RCA). Although it can be hazardous to connect mRNA levels to their respective protein contents (Boschetti et al., 1990; Eckardt and Pell, 1994; Glick et al., 1995; Moore et al., 1998), we also determined carboxylase protein contents. Simultaneously, we quantified chlorophylls and carotenoids since photosynthetic pigment degradation is regarded as a reliable parameter to estimate leaf senescence which is known to be ozoneaccelerated in $\mathrm{C}_{3}$ plants (Matile et al., 1999; Pell et al., 1999; Calatayud and Barreno, 2004). All analyses were carried out on leaves from maize plants (Zea mays, L. cv. Chambord) exposed, at different development stages, to chronic and realistic ozone stresses. Concretely, we performed two fumigation experiments in order to compare the response of a lower $\left(5^{\text {th }}\right.$ leaf) and of an upper leaf $\left(10^{\text {th }}\right.$ leaf) to two polluted atmospheres enriched with 40 and $80 \mathrm{~nL} \mathrm{~L}^{-1}$ ozone, respectively; both leaves being fumigated during their growing period.

\section{MATERIALS AND METHODS}

\subsection{Ozone treatment}

The experiments were conducted at Montardon $\left(43^{\circ} \mathrm{N}, 0^{\mathrm{e}} 30^{\prime} \mathrm{W}\right.$, attitude $200 \mathrm{~m}$ above the sea level), $10 \mathrm{~km}$ north of Pau, France. Three atmospheres were experimented in open-top chambers (OTCs): non-filtered air (NF, control) and 2 ozone-enriched treatments using nonfiltered air containing $40 \mathrm{~nL} \mathrm{~L}^{-1}(+40)$, and $80 \mathrm{~nL} \mathrm{~L} \mathrm{~L}^{-1}(+80)$ ozone. Technical characteristics of OTCs, fumigation system, the monitoring and the computing of ozone data were previously detailed elsewhere (Junqua et al., 2000). Supplemental ozone was applied from 10:00 to $17: 00 \mathrm{~h}$ Greenwich mean time (GMT) in order to simulate the normal period of ozone exposure. For each atmosphere, seasonal 7$\mathrm{h}$ mean ozone concentration was computed from ozone hourly means between 10:00 and 17:00 h. Ozone dose was calculated as an Accumulated exposure Over a Threshold of $40 \mathrm{~nL} \mathrm{~L}^{-1}$ (AOT40) for each daylight hour with global radiation of $50 \mathrm{~W} \mathrm{~m}^{-2}$ or greater, as defined for critical levels for ozone vegetation effects in Europe (Karenlampi and Skarby, 1996; Grünhage et al., 1999). Thus AOT40 ( $\left.\mathrm{nL} \mathrm{L}^{-1} \mathrm{~h}\right)$ is the sum of the differences between the hourly mean ozone concentration and $40 \mathrm{~nL} \mathrm{~L}^{-1}$ for each hour when ozone concentration exceeds $40 \mathrm{~nL} \mathrm{~L}^{1}$, accumulated from leaf emergence until sampling. The appearance of the lamina tip out of the whorl defined the leaf emergence date.

\subsection{Crop management, ozone exposure, sampling process}

Maize leaves were numbered from the basis to the top of the plant, the first leaf being the first appeared leaf and then the oldest leaf. A maize leaf is considered as fully expanded when its collar is visible. Two experiments were performed: the first experiment aimed to quantify the ozone impact on a lower leaf ( $5^{\text {th }}$ leaf) sampled on young plants exposed for 33 days from emergence (19 May) and the second experiment aimed to detect the impact of an almost similar ozone stress on an upper leaf $\left(10^{\text {th }}\right.$ leaf $)$ sampled on older maize plants exposed for 28 days from the full expansion of the $7^{\text {th }}$ leaf ( 21 June). From sowing until 21 June, these plants were grown in ambient air. Fifty-seven 2-L (19 for each atmosphere) and 27 12-L (9 for each atmosphere) base-perforated plastic pots filled with universal compost, were prepared for experiment 1 and 2, respectively. Although it may influence the plant microenvironment, the size of pots was chosen according to the plant development expected at the final harvest, for each experiment. Five maize caryopses (Zea mays, L. cv. Chambord) were sown per pot on 13 May. A very homogeneous emergence (about 95\%) was recorded on 18 May and 19 May for 2-L pots placed in OTCs and $12-\mathrm{L}$ pots maintained in ambient air, respectively. The number of plants per pot was gradually reduced to keep 1 plant per pot 10 days after emergence (DAE). During experiments, plants were always well-watered to avoid water stress effects 
and fertilized once a week with an NPK fertilizer $(20: 10: 10)$ enriched in micronutrients. In experiment 1, 15 plants exhibiting 7 fully expanded leaves were harvested from each OTC 38 days after planting (33 DAE). In experiment 2 , pots were distributed in the 3 OTCs on 21 June as maize plants exhibited 7 fully expanded leaves. Five maize plants per OTC were harvested 28 days later (61 DAE) as they displayed 13 fully expanded leaves. For each experiment, leaves were harvested in the early afternoon to avoid any influence of diurnal cycling on gene expression. The collected leaves were immediately frozen in liquid nitrogen and individually stored at $-80^{\circ} \mathrm{C}$ until analysis. Since the $5^{\text {th }}$ leaf was not large enough, extractions of transcripts, pigments and proteins were performed on three different $s e t s$ of $5^{\text {th }}$ leaves (5 leaves per set and per atmosphere). Regarding the large $10^{\text {th }}$ leaf, these 3 extractions were done on the same leaf so that only one set of $10^{\text {th }}$ leaves was used (5 leaves per atmosphere). Analyses were carried out on the central part of each collected leaf.

\subsection{Pigment extraction and analysis}

For each experiment, 5 leaves per atmosphere were analysed. For each sampled leaf, the determination of pigment content was achieved from analysis of 4 foliar discs of $1.131 \mathrm{~cm}^{2}$ each. The discs from the $5^{\text {th }}$ leaf were processed by pairs whereas those from the $10^{\text {th }}$ leaf were individually analysed. Each disc pair or individual disc was ground with liquid nitrogen. Pigments were extracted by incubating leaves in $5 \mathrm{~mL}$ acetone $80 \%$ (v/ v) for $24 \mathrm{~h}$ at $4{ }^{\circ} \mathrm{C}$ in darkness. The absorbance of leaf pigment extracts was measured at 470, 646.8 and $663.2 \mathrm{~nm}$. Concentrations of chlorophyll a, b, total chlorophylls $(\mathrm{a}+\mathrm{b})$ and total carotenoids were calculated according to extinction coefficients and equations reported by Lichtenthaler (1987). Finally, data from either two pairs of discs ( $5^{\text {th }}$ leaf) or from 4 individual discs (10 $10^{\text {th }}$ leaf) were averaged and the obtained mean concentration was expressed as $\mu \mathrm{g} \mathrm{cm}^{-2}$ of leaf.

\subsection{Protein extraction and analysis}

For each experiment, 5 leaves per atmosphere were analysed. Leaves were coarsely ground in a mortar under liquid nitrogen. Soluble proteins were extracted by reducing $600 \mathrm{mg}$ of this ground to powder in a mortar with $6 \mathrm{~mL}$ of $0.1 \mathrm{M}$ (Tris(hydroxymethyl)aminomethane)-HCl (Tris- $\mathrm{HCl}, \mathrm{pH} 7.5), 5 \mathrm{mM}$ ethylene glycolbis( $\beta$-aminoethyl ether)-tetraacetic acid (EGTA), 1 mM phenylmethylsulfonyl fluoride (PMSF), $1 \mu \mathrm{M}$ pepstatin, $2 \mathrm{mM}$ dithiothreitol (DTT), $5 \mathrm{mM} \mathrm{MgCl} 2,10 \mathrm{mM}$ $\mathrm{NaHCO}_{3}, \quad 1.5 \% \quad(\mathrm{w} / \mathrm{v})$ polyvinylpolypyrrolidone and $5 \mu \mathrm{g} \mathrm{mL}-1$ leupeptin. After centrifugation at $17608 \mathrm{~g}$ at $4^{\circ} \mathrm{C}$ for $15 \mathrm{~min}$, proteins present in the supernatant were precipitated according to Leitao et al. (2003). After a new centrifugation $\left(17608 \mathrm{~g}, 4^{\circ} \mathrm{C}, 10 \mathrm{~min}\right)$, pellets were resuspended in $200 \mu \mathrm{L}$ of extraction buffer. Protein concentrations were determined by the procedure of Bradford (1976) using a protein assay reagent (Biorad) and bovine serum albumin as a standard. Estimation of Rubisco-SSU, Rubisco-LSU and PEPc quantities were performed according to a previously published procedure (Kanoun et al., 2002; Leitao et al., 2003). Relative amounts of Rubisco-SSU, Rubisco-LSU and PEPc were expressed as a percentage of soluble proteins.

\subsection{RNA analysis}

\subsubsection{RNA extraction}

For each experiment, 5 leaves were analysed per atmosphere. The central part of each lamina was ground in a mortar with liquid nitrogen. Approximately $0.1 \mathrm{~g}$ of the powder was transferred to a $2 \mathrm{~mL}$ microcentrifuge tube. Total RNA was extracted with Plant Rneasy kit (Quiagen) according to manufacturer's instructions. Quantitative and qualitative integrity measurements of RNAs were assessed by absorbance ratio $\left(\mathrm{A}_{260 \mathrm{~nm}}\right.$ / $\left.\mathrm{A}_{280 \mathrm{~nm}}\right)$ and by capillary electrophoresis using a Bioanalyser 2100 (Agilent Technologies), respectively. RNA extracts were stored at $-80^{\circ} \mathrm{C}$. 


\subsubsection{RNA preparation and reverse transcription $(R T)$}

One $\mu \mathrm{g}$ of RNA was made free of DNA by incubating with DNAse I for $15 \mathrm{~min}$ at $25^{\circ} \mathrm{C}$, according to the recommendations of the supplier (Sigma). This DNA degradation process was followed by (i) thermal inactivation of the enzyme in presence of 50 $\mathrm{mM}$ EDTA $\left(70^{\circ} \mathrm{C}, 10 \mathrm{~min}\right)$ and (ii) a rapid cooling down to $4^{\circ} \mathrm{C}$. Reverse transcription (RT) reactions were performed with Superscript III First-Strand Synthesis System for RT-PCR following manufacturer's instructions (Invitrogen) in a PTC 200 thermocycler (MJ Research, Watertown, MA). To minimize possible variations of cDNA synthesis during RT process, six separate RT reactions were performed and pooled for each RNA extract. Then, $2.5 \mu \mathrm{M}$ oligo $(\mathrm{dT})_{20}$ primers and $0.5 \mathrm{mM}$ dNTP were hybridised to DNase-treated total RNA in a volume of $10 \mu \mathrm{L}$ by heating up to $65^{\circ} \mathrm{C}$ for 5 min, then placed on ice. First-strand cDNA was synthesised by incubating the previous RNA-containing mixture with $1 \mathrm{X}$ RT buffer, $5 \mathrm{mM} \mathrm{MgCl} 2,0.01 \mathrm{M} \mathrm{DTT}, 40$ units RNase OUT and 200 units Superscript III RT in a $20 \mu \mathrm{L}$ final reaction volume. The $\mathrm{RT}$ reaction was performed sequentially for 50 $\min$ at $50^{\circ} \mathrm{C}$, for $5 \mathrm{~min}$ heating at $85^{\circ} \mathrm{C}$ and a rapid cooling down to $4^{\circ} \mathrm{C}$ followed by RNase $\mathrm{H}$ treatment (Invitrogen). cDNAs were immediately used and/or stored at $20^{\circ} \mathrm{C}$ until analysis. In order to test cDNA amplification products specificity, a reverse transcription reaction without enzyme was simultaneously performed.

\subsubsection{Primer designs}

The PCR primers were designed using Primer Express 2.0 software (Applied Biosystems). Each gene sequence was obtained from public database. Each primer was designed to produce approximately a 100 bp-amplicon according to Applied Biosystems' recommendations. Primer sequences for amplification of $\mathrm{C}_{4}{ }^{-}$ phosphoenolpyruvate carboxylase $(P E P c)$, Ribulose-1,5-bisphosphate carboxylase small subunit (Rubisco-SSU), Ribulose-1,5bisphosphate carboxylase large subunit (Rubisco-LSU), ribulose-1,5-bisphosphate carboxylase/oxygenase activase $(R C A)$ and maize actin genes by real-time PCR are listed in Table 1. Rubisco-SSU primers were designed to fit both Rubisco-SSU genes described in literature (Hanhen et al., 2003). Gene specificity of each primer was confirmed throughout BLAST searches in public databases. Furthermore, the specificity of RT-PCR products was assessed by monitoring the dissociation curves after real-time RT-PCR reactions in ABI Prism 5700 sequence detection System (Perkin-Elmer Applied Biosystems) and analysing their size using electrophoresis with ethidium bromide staining on a $4 \%$ agarose gel.

TABLE 1

Sequences of oligonucleotide primers used for real-time RT-PCR

\begin{tabular}{llllc}
\hline Oligo name & Accession & $\begin{array}{l}\text { Oligonucleotide sequence (5' to 3') } \\
\text { Forward }\end{array}$ & Reverse & $\begin{array}{l}\text { Product } \\
\text { size (bp) }\end{array}$ \\
\hline Actin & J 01238 & GATGGTCAGGTCATCACCATTG & AACAAGGGATGGTTGGAACAAC & 76 \\
PEPc & X 15238 & AGCCTTCAGAACCGATGAAATC & CATCCCATAGCGCATTTCG & 67 \\
Rubisco-SSU & D 00170 & ATGTGGAAGCTGCCCATGTT & GCCTCCTGCAGCTCCTTGTA & 65 \\
Rubisco-LSU & Z 11973 & AAAGCCTTACGCGCTCTACGT & CGGACCTTGGAAAGTTTTTGAA & 72 \\
Rubisco Activase & AF 084478 & CTTCATGACCCTGCCAAACA & GATTTTCCCTGGCCTTTGC & 72 \\
\hline
\end{tabular}

b BLAST analysis (www.ncbi.gov/BLAST) showed that all primers have $100 \%$ homology with their intended target sequence, i.e. are specific. 


\subsubsection{Real-time RT-PCR}

Real-time RT-PCR was carried out using SYBR Green PCR master mix (Applied Biosystems) in the ABI Prism 5700 Sequence detection system (Perkin-Elmer Applied Biosystems) with a GeneAmp 5700 PCR thermocycler, according to the protocol provided by the supplier. Triplicate amplification reactions were performed in $20 \mu \mathrm{L} 1 \mathrm{X}$ SYBR Green PCR master mix containing $300 \mathrm{nM}$ of each primer (forward and reverse) and $5 \mu \mathrm{L}$ cDNA. PCR parameters were those recommended by the manufacturer. Melt curves and derivative melt curves were run after the last PCR cycle. Melt curves were produced by plotting the fluorescence intensity versus temperature as the temperature increased from 60 to $95^{\circ} \mathrm{C}$. The real-time RT-PCR efficiency was determined for each gene with the slope of a linear regression model (Pfaffl, 2001) by measuring the $\mathrm{Ct}$ value to a specific threshold for a serial dilution of RNA (Walker, 2002). Since all RT-PCR efficiencies were above $98 \%$, the comparative $\mathrm{Ct}$ method which was similar to the standard curve method (Applied Biosystems User Bulletin \#2), was used. The use of GeNorm software (Vandesompele et al., 2002) as well as Brunner et al.'s procedure (Brunner et al., 2004) showed that the expression of actin, a housekeeping gene, was stable enough to be used as an internal standard for RT-PCR to allow normalization of real-time RT-PCR data. Normalized amplification data are calculated and expressed as 2(Ctactin- Ctgene), where $\mathrm{Ct}$ corresponds to the number of cycles needed to generate a fluorescent signal above a predefined threshold (Ferry et al., 2003).

\subsection{Statistical analysis}

For each treatment, results are expressed as means associated with standard error (SE). The significance of ozone treatment impacts were tested using a one-way analysis of variance (ANOVA). Each time a significant difference was accepted $(p<0.05)$, groups of homogeneous means were detected with the help of a NewmanKeuls test based on the minimum significant range (Sokal and Rohlf, 2001). All statistical analyses were carried out using STATBOX (version 6.4) software package.

\section{RESULTS}

\subsection{Ozone exposure and visible foliar damage}

Ozone data recorded in $\mathrm{NF},+40$ and +80 treatments are reported in Table 2. In control treatments, the $5^{\text {th }}$ and $10^{\text {th }}$ leaves were exposed to seasonal 7 -h mean ozone concentrations of 48 and $36 \mathrm{~nL} \mathrm{~L}^{-1}$, respectively. In experiment 1 , the ozone concentrations registered in +40 and +80 regimens during the $7-\mathrm{h} \mathrm{O}_{3}$-enrichment were roughly 1.8 - and 2.6-fold that of the ambient control (NF), respectively. In experiment 2 , they were roughly 2.1 - and 3.2-fold that of NF. Although the external AOT40 ozone dose experienced by the $5^{\text {th }}$ leaf in control treatment (NF) was 2.8-fold greater than that experienced by the $10^{\text {th }}$ leaf, both leaves were exposed to almost similar AOT40 doses in each of the two ozone-enriched treatments. The AOT40 ozone dose that the $5^{\text {th }}$ and the $10^{\text {th }}$ leaves received in +80 atmosphere was about 2 fold superior to that computed in +40 atmosphere.

At the date of their respective harvest, no visible damage was exhibited by the $5^{\text {th }}$ and $10^{\text {th }}$ leaves from control atmosphere (NF). Tenth leaves from +40 and +80 atmospheres appeared as healthy as those from NF conditions: neither colour change nor particular necrosis could be observed on their laminae. Conversely, $5^{\text {th }}$ leaves from ozone-enriched atmospheres exhibited senescence symptoms crescent with the external ozone dose: chlorosis was more pronounced in +80 atmosphere than in +40 atmosphere. Moreover, in +80 atmosphere the lamina tip $(1.5-2 \mathrm{~cm})$ of the yellowish $5^{\text {th }}$ leaf was completely withered. In any case the senescence proceeded in the same manner as leaf development: from the top of the leaf (made of older cells) to the base (made of younger cells). 
Ozone data recorded in the three tested atmospheres according to the experiment

Experiments 1 and 2 were carried out to study the ozone impact on the $5^{\text {th }}$ and the $10^{\text {th }}$ maize leaf, respectively. For each experiment, seasonal 7-h (between 10:00 and 17:00 $\mathrm{h}$ GMT) mean $\mathrm{O}_{3}$ concentrations $\left(\mathrm{nL} \mathrm{L} \mathrm{L}^{-1}\right)$ were computed from the beginning of the exposure until harvest date. External $\mathrm{O}_{3}$ doses expressed as AOT40 [Accumulated exposure Over a Threshold of $40 \mathrm{~nL} \mathrm{~L}^{-1} \mathrm{O}_{3}\left(\mathrm{~nL} \mathrm{~L}^{-1} \mathrm{~h}\right)$, see Materials and Methods] were computed from emergence of the sampled leaf until its harvest. NF, chambered non-filtered air (control); $+40,+80$, chambered non-filtered air plus 40 and $80 \mathrm{~nL} \mathrm{~L}^{-1} \mathrm{O}_{3}$, respectively.

\begin{tabular}{cccccc}
\hline \multirow{2}{*}{ Atmosphere } & \multicolumn{2}{c}{ Experiment 1 (5 $5^{\text {th }}$ leaf $)$} & & \multicolumn{2}{c}{ Experiment 2 $\left(10^{\text {th }}\right.$ leaf $)$} \\
\cline { 2 - 3 }$\left(\begin{array}{c}\text { Ozone concentration } \\
\left(\mathrm{nL} \mathrm{L} \mathrm{L}^{-1}\right)\end{array}\right.$ & $\begin{array}{c}\text { AOT40 } \\
\left(\mathrm{nL} \mathrm{L}^{-1} \mathrm{~h}\right)\end{array}$ & & $\begin{array}{c}\text { Ozone concentration } \\
\left(\mathrm{nL} \mathrm{L} \mathrm{L}^{-1}\right)\end{array}$ & $\begin{array}{c}\text { AOT40 } \\
\left(\mathrm{nL} \mathrm{L}^{-1} \mathrm{~h}\right)\end{array}$ \\
\hline $\mathrm{NF}$ & 48 & 1281 & & 36 & 463 \\
+40 & 86 & 7170 & & 76 & 7094 \\
+80 & 124 & 12782 & & 114 & 14539 \\
\hline
\end{tabular}

\subsection{Ozone effect on photosynthetic pigment content}

As shown in Figure 1, the photosynthetic pigmentations of the $5^{\text {th }}$ and $10^{\text {th }}$ leaves were differentially affected by ozone.

Regarding the $5^{\text {th }}$ leaf, pigment data matched the visual aspect of the lamina. In control atmosphere (NF), total chlorophyll and total carotenoid contents were on average, $47.40 \mu \mathrm{g} \mathrm{cm} \mathrm{cm}^{-2}$ and $7.37 \mu \mathrm{g} \mathrm{cm} \mathrm{cm}^{-2}$, respectively. A decline in total chlorophylls by about 35 and $47 \%$ was evidenced in +40 and +80 treatments, respectively, relative to the control (NF). Such a significant reduction $(p<0.001)$ can be ascribed to consistent losses in both Chl a $(p<0.001)$ and $\mathrm{Chl} \mathrm{b}(p<0.001)$ (Fig. 1). However, as suggested by the $\mathrm{Chl} \mathrm{a} / \mathrm{b}$ ratio, $\mathrm{Chl}$ a tended to be more affected than $\mathrm{Chl} \mathrm{b}(p<0.01)$. This trend became significant only in the highest ozone-enriched treatment $(+80)$. Indeed, in +80 atmosphere Chl a was decreased by $52 \%$ whereas Chl b was decreased by only $35 \%$, compared to the control. The ozone-induced decline in total carotenoid content was also significant $(p<0.001)$ and almost similar to the reduction in total chlorophylls. Therefore, total carotenoids were decreased by $32 \%$ and $54 \%$ in +40 and +80 treatments, respectively. However, the $\mathrm{Chl} \mathrm{a}+\mathrm{b} /$ total
Car ratio was slightly but consistently $(p<0.05)$ increased in +80 treatment. This result suggests that carotenoids might be more sensitive to ozone than chlorophylls.

Regarding the $10^{\text {th }}$ leaf, ozone-induced changes in pigment content were accompanied by no change in leaf colour that could be visually assessed. Under normal atmosphere, the $10^{\text {th }}$ leaf was richer in photosynthetic pigment than the $5^{\text {th }}$ leaf. In mature $10^{\text {th }}$ leaf from NF atmosphere, Chl a, Chl b and total carotenoid concentrations were about $42 \%, 15 \%$ and $60 \%$ higher than in the control mature $5^{\text {th }}$ leaf, respectively. Therefore, in the control upper leaf $\left(10^{\text {th }}\right)$, Chl a/b ratio was definitely greater whereas $\mathrm{Chl} a+b /$ total Car was lower, relative to the control lower leaf $\left(5^{\text {th }}\right)$. In any case, ozone was also able to significantly modify total chlorophyll $(p<0.001)$, Chl a $(p<0.001)$, Chl b $(p<0.001)$ and total carotenoid $(p<0.001)$ contents in the $10^{\text {th }}$ leaf (Fig. 1). However, its effect was more complex than that observed for the $5^{\text {th }}$ leaf. Indeed, a moderate addition of $40 \mathrm{~nL} \mathrm{~L}^{-1}$ ozone to the ambient concentration (+40 atmosphere) consistently increased total chlorophylls $(+36 \%), \mathrm{Chl}$ a $(+37 \%), \mathrm{Chl} \mathrm{b}(+34 \%)$ and total carotenoids $(+30 \%)$, relative to the control. This stimulation of pigment accumulation affected neither $\mathrm{Chl} \mathrm{a} / \mathrm{b}$ ratio 
$5^{\text {th }}$ leaf
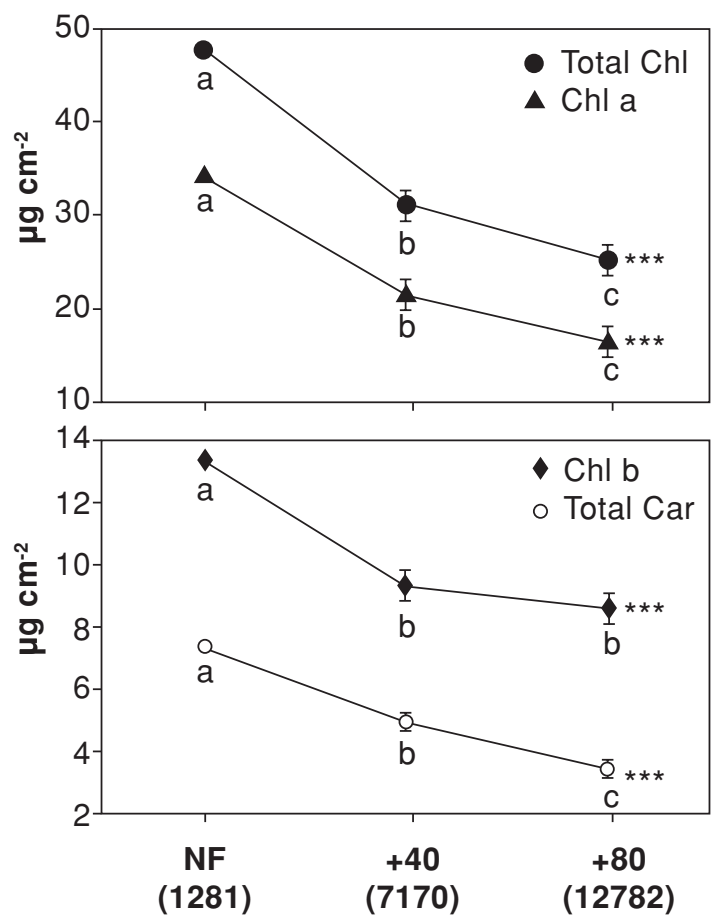

Atmosphere (AOT40, $\mathrm{nL} \mathrm{L}^{-1} \mathrm{~h}$ ) $10^{\text {th }}$ leaf
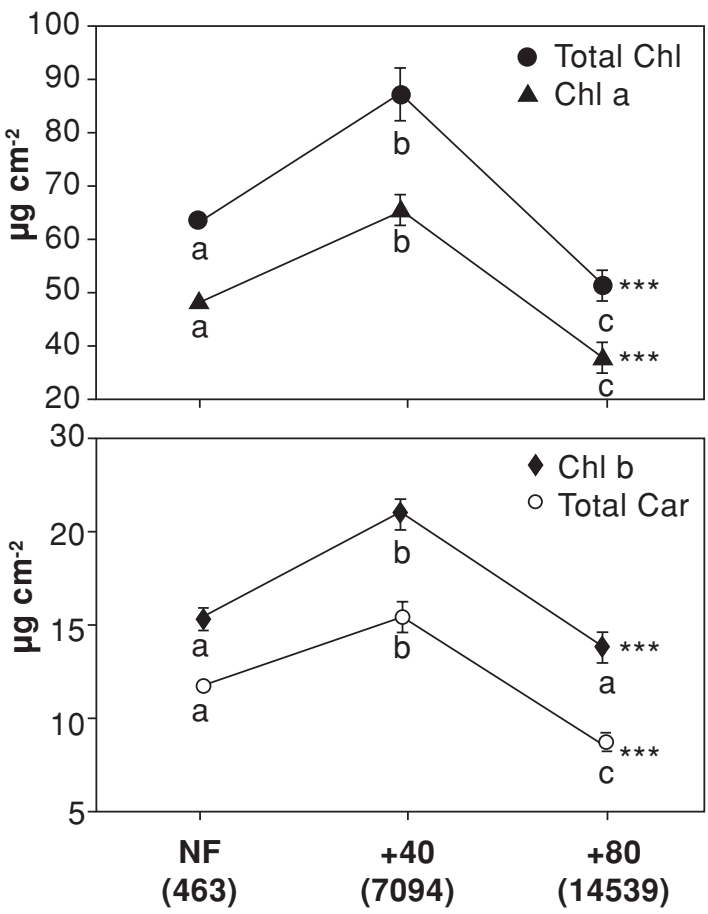

Atmosphere (AOT40, $\mathrm{nL} \mathrm{L}^{-1} \mathrm{~h}$ )

Figure 1: Total chlorophylls $(\mathbf{O})$, chlorophyll a $(\mathbf{\Delta})$, chlorophyll b $(\diamond)$ and total carotenoids $(\mathrm{O})$ accumulated in control and ozone-treated maize leaves $\left(5^{\text {th }}\right.$ leaf and $10^{\text {th }}$ leaf). NF, chambered nonfiltered air; $+40,+80$ chambered non-filtered air plus $40,80 \mathrm{~nL} \mathrm{~L}^{-1} \mathrm{O}_{3}$, respectively. External ozone doses accumulated by the leaves are provided as AOT40 values ( $\mathrm{nL} \mathrm{L}^{-1} \mathrm{~h}$; see Materials and Methods). Data are presented as mean values $(n=5)$. Vertical bars represent standard errors (SE). Results of a one-way ANOVA: ***, $p<0.001$; **, $p<0.01$; *,$p<0.05$. When significance was accepted $(p<0.05)$, means were compared with a Newman-Keuls test: means identified with the same letter are not significantly different $(p>0.05)$.

nor $\mathrm{Chl} \mathrm{a}+\mathrm{b} /$ total Car ratio. Conversely, the highest polluted atmosphere $\left(+80 \mathrm{~nL} \mathrm{~L}^{-1}\right.$ ozone) induced a significant decline in total chlorophylls $(-22 \%)$, Chl a $(-26 \%)$, Chl b ($12 \%)$ and total carotenoids $(-25 \%)$, relative to the control. As already observed in the $5^{\text {th }}$ leaf, $\mathrm{Chl}$ a was much more reduced by ozone than $\mathrm{Chl} \mathrm{b}$ and the extent of reduction in total carotenoid content was close to that registered for $\mathrm{Chl}$ a. The preferential degradation of $\mathrm{Chl}$ a, relative to $\mathrm{Chl} b$, was underlined by the significant fall in the Chl $\mathrm{a} / \mathrm{b}$ ratio $(p<0.01)$. In the same way as for the $5^{\text {th }}$ leaf, the Chl a+b/total Car ratio determined in the $10^{\text {th }}$ leaf appeared rather insensitive to the deleterious ozone effects.

\subsection{Specificity of real-time $R T-P C R$ reaction}

For each primer set, the specificity of SYBR Green detection of real-time RTPCR products was assessed by dissociation curve analysis and agarose gel electrophoresis. For example, regarding Rubisco-LSU, a single dissociation peak was obtained for an experimental melting temperature $(\mathrm{Tm})$ of $78^{\circ} \mathrm{C}$ that was very close to the theoretical $\mathrm{Tm}$ of $79^{\circ} \mathrm{C}$. The presence of a single amplification product was confirmed by gel electrophoresis where only a single band, with a predicted size of $72 \mathrm{bp}$, was visible. All these data indicated 
that Rubisco-LSU real-time RT-PCR assay was gene-specific and could not be confused with non-specific amplification and/or primer dimer. Melting curves and gel analyses for all other primer sets (Rubisco-SSU, Rubisco activase and PEPc) matched well.

\subsection{Ozone impact on PEP carboxylase (transcripts and protein)}

Ozone was able to reduce PEPc transcripts in the $5^{\text {th }}$ leaf $(p<0.001)$ as well as in the $10^{\text {th }}$ leaf $(p<0.01)$ (Fig. 2). However, the effect of a given external ozone dose on PEPc mRNA levels could vary with leaf rank. Indeed, an AOT40 of $7170 \mathrm{~nL} \mathrm{~L}^{-1} \mathrm{~h}$ (achieved in +40 atmosphere) significantly reduced the PEPc transcripts by $59 \%$ in the $5^{\text {th }}$ leaf whereas an almost similar external ozone dose of $7094 \mathrm{~nL} \mathrm{~L}^{-1} \mathrm{~h}$ (also achieved in +40 atmosphere) did not change their amount in the $10^{\text {th }}$ leaf. In any case, the highest ozone dose accumulated in +80 atmosphere significantly decreased PEPc mRNA in both $5^{\text {th }}(-59 \%)$ and $10^{\text {th }}(-79 \%)$ leaf. In control atmosphere (NF), the foliar relative amount of PEPc protein did not vary significantly between lower and upper leaves $(p=0.370)$. On the average, PEPc protein accounted for circa $15 \%$ of soluble proteins extracted from the $5^{\text {th }}$ leaf whereas, in the $10^{\text {th }}$ leaf, it accounted for circa $14 \%$ of soluble proteins. The $\mathrm{O}_{3}$-induced variations in PEPc protein content roughly reflected changes observed in mRNA quantities even if depletion percentages were not always comparable (Fig. 2). Regarding the $5^{\text {th }}$ leaf, a significant reduction in PEPc protein was noticed exclusively in +80 atmosphere $(-44 \%$, relative to the control) whereas transcripts were already drastically reduced in +40 atmosphere. As previously described for transcripts, +40 atmosphere did not consistently change the PEPc protein $5^{\text {th }}$ leaf

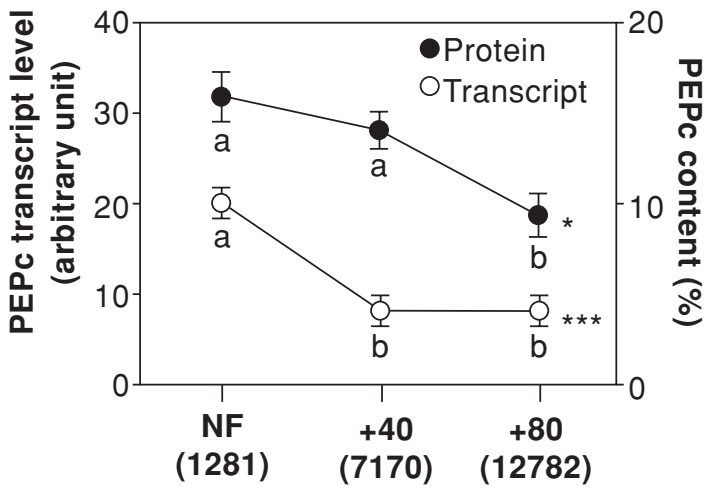

Atmosphere

(AOT40, $\mathrm{nL} \mathrm{L}^{-1} \mathrm{~h}$ ) 10th leaf

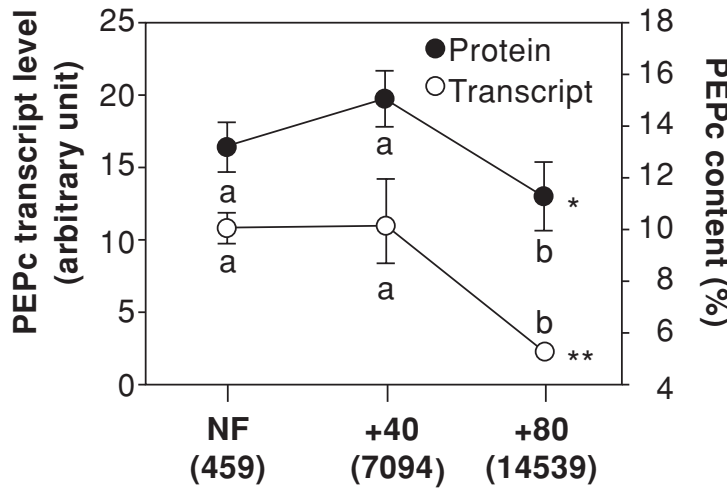

Atmosphere
(AOT40, nL L-1 h)

Figure 2: PEPc transcript levels $(\mathrm{O})$ and PEPc protein amounts $(O)$ determined in $5^{\text {th }}$ and $10^{\text {th }}$ leaves from maize plants exposed to three increasing $\mathrm{O}_{3}$ concentrations. Relative quantification of PEPc transcripts (arbitrary units) was performed by real-time RT-PCR with actin as housekeeping gene. Amount of PEPc protein was expressed as percentage of soluble proteins. NF, chambered non filtered air; $+40,+80$ chambered non-filtered air plus $40,80 \mathrm{~nL} \mathrm{~L}^{-1} \mathrm{O}_{3}$, respectively. External ozone doses accumulated by the leaves are provided as AOT40 values ( $\mathrm{nL} \mathrm{L}^{-1} \mathrm{~h}$; see Materials and Methods). Data are presented as mean values $(n=5)$. Vertical bars represent standard errors (SE). Results of a one-way ANOVA: ***, $p<0.001$; **, $p<0.01$; *, $p<0.05$. When significance was accepted $(p<0.05)$, means were compared with a Newman-Keuls test: means identified with the same letter are not significantly different $(p>0.05)$. 
content in the $10^{\text {th }}$ leaf whereas +80 atmosphere significantly reduced the protein by $25 \%$, i.e. 3 -fold less than mRNA quantities. In the atmosphere with highest pollution $(+80)$, the percentage of PEPc protein was more severely depressed in the $5^{\text {th }}$ leaf $(-44 \%)$ by an AOT40 of $14539 \mathrm{~nL}$ $\mathrm{L}^{-1} \mathrm{~h}$ than in the $10^{\text {th }}$ leaf $(-25 \%)$ for an almost comparable AOT40 of $12782 \mathrm{~nL} \mathrm{~L}^{-1}$ $\mathrm{h}$.

\subsection{Ozone impact on Rubisco (transcripts and protein)}

The ozone impact on the accumulation of mRNAs encoding both Rubisco-SSU and Rubisco-LSU is displayed in Figure 3. Whatever the tested atmosphere, the amounts of SSU and LSU transcripts extracted from the $5^{\text {th }}$ leaf remained statistically stable $(p=0.338$ and $p=0.634$ for SSU and LSU, respectively). This was also true for LSU mRNA from the $10^{\text {th }}$ leaf $(p=0.231)$ in spite of a trend towards an increase in both ozone-enriched atmospheres as compared to the control $(\mathrm{NF})$. Also in the $10^{\text {th }}$ leaf, this trend became significant for SSU $(p<0.001)$ : the level of SSU transcripts increased by $338 \%$ and $59 \%$, in +40 and +80 atmosphere, respectively, relative to NF. Focusing on Rubisco protein, it appeared that the control $10^{\text {th }}$ leaf was slightly richer $(p=0.018)$ in Rubisco-SSU (circa $12 \%$ of soluble proteins) than the control $5^{\text {th }}$ leaf (circa $8 \%$ of soluble proteins) (Fig. 3). In contrast, from a statistical viewpoint, these two leaves contained similar average amounts of Rubisco-LSU ( $p=0.170$ ): about $24 \%$ for the $5^{\text {th }}$ leaf and $26 \%$ for the $10^{\text {th }}$ leaf. In the $10^{\text {th }}$ leaf, the amounts of both Rubisco subunits were not consistently disturbed by ozone ( $p=0.055$ and $p=0.062$ ) even if, they tended to respond to increasing ozone concentration in the same way as transcripts did. As compared to the control, a small average increase was observed in +40 atmosphere $(+14 \%$ for SSU and $+13 \%$ for LSU) whereas a small average reduction was noticed in +80 atmosphere $(-11 \%$ for SSU and $-12 \%$ for LSU). With regard to the $5^{\text {th }}$ leaf, SSU and LSU proteins exhibited a response to ozone distinct from that shown by their corresponding transcripts. Indeed, ozone significantly reduced both SSU $(p<0.001)$ and LSU $(p<0.01)$ proteins. However, these declines were reliable only in +80 atmosphere: $-31 \%$ for SSU and $-29 \%$ for LSU.

\subsection{Ozone impact on Rubisco activase transcripts}

Accumulation of transcripts encoding Rubisco activase did not seem very sensitive to ozone exposure (Fig. 4). Despite the occurrence of mean variations in transcript amounts that could reach 50\% relative to the control, no significant changes were statistically assessed probably because of some important withinatmosphere variances. However, RCA mRNAs from the $5^{\text {th }}$ and $10^{\text {th }}$ leaves clearly showed distinct trends in their response to ozone. Indeed, as quantities of RCA mRNAs accumulated in the $5^{\text {th }}$ leaf decreased by $-37 \%$ and $-44 \%$ in +40 and +80 atmosphere, respectively and relative to the control, RCA mRNAs accumulated in the $10^{\text {th }}$ leaf increased by $50 \%$ and $36 \%$.

\section{DISCUSSION}

\section{Ozone and maize pigments}

The control $10^{\text {th }}$ leaf accumulated larger amounts of photosynthetic pigments ( $\mathrm{Chl}$ a, Chl b and Car) than the control $5^{\text {th }}$ leaf. The $5^{\text {th }}$ leaf is a small leaf as compared to the $10^{\text {th }}$ leaf. Despite its rather short lifespan, the $5^{\text {th }}$ leaf sampled in control atmosphere was particularly healthy. It exhibited no visible sign of senescence at the harvest date. Thus, the difference in pigment content between control $5^{\text {th }}$ and $10^{\text {th }}$ leaf could be ascribed to (i) a pigment loss in the $5^{\text {th }}$ leaf resulting from a natural senescence process which is not sufficiently advanced to be visually assessed or/and (ii) a greater pigment accumulation in the $10^{\text {th }}$ leaf that could be variously explained. Focusing on this last hypothesis, the increase in pigment content measured in the $10^{\text {th }}$ leaf does not necessarily mean that thylakoids are richer in pigments or/and 
$5^{\text {th }}$ leaf

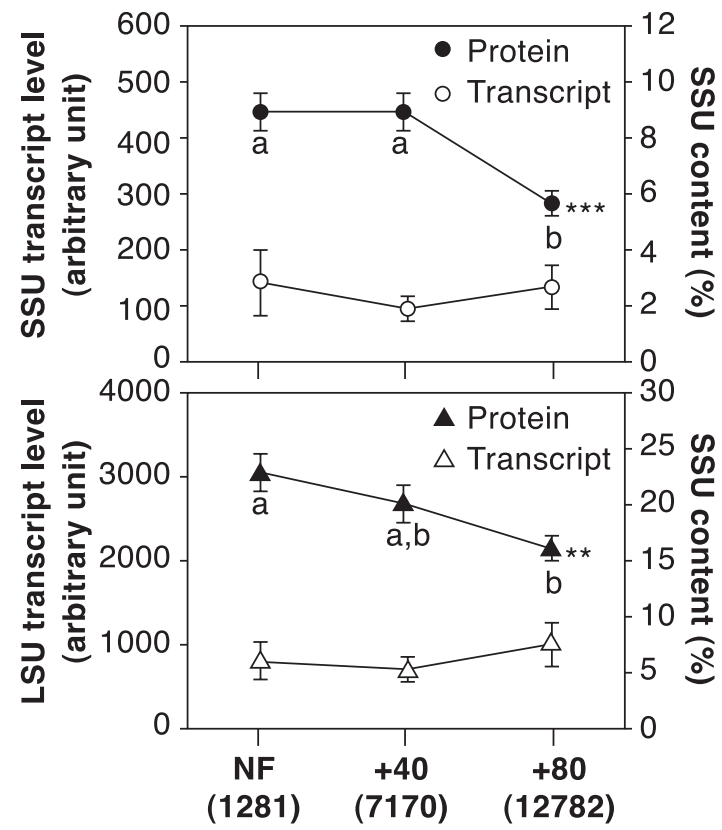

Atmosphere

(AOT40, $\mathrm{nL} \mathrm{L}^{-1} \mathrm{~h}$ ) $10^{\text {th }}$ leaf

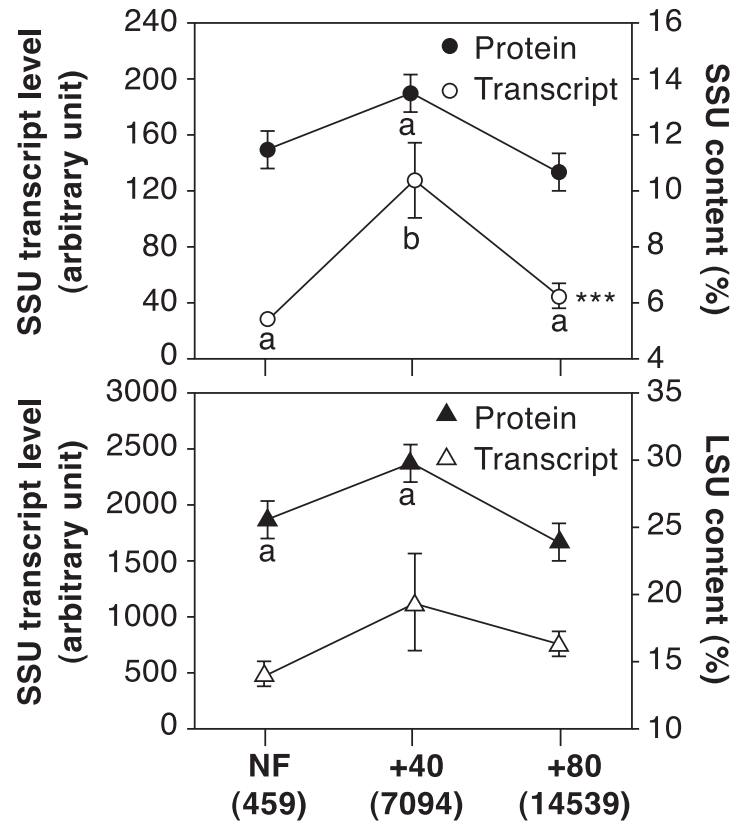

Atmosphere

(AOT40, $\mathrm{hL} \mathrm{L}^{-1} \mathrm{~h}$ )

Figure 3: Rubisco-SSU (O), Rubisco-LSU $(\Delta)$ transcript levels and Rubisco-SSU (๑), RubiscoLSU $(\boldsymbol{\Delta})$ protein amounts determined in $5^{\text {th }}$ and $10^{\text {th }}$ leaves from maize plants exposed to three increasing $\mathrm{O}_{3}$ concentrations. Relative quantification of Rubisco transcripts (arbitrary units) was performed by real-time RT-PCR with actin as housekeeping gene. Amounts of Rubisco-SSU and Rubisco-LSU subunits were expressed as percentage of soluble proteins. NF, chambered non filtered air; $+40,+80$ chambered non-filtered air plus $40,80 \mathrm{~nL} \mathrm{~L}^{-1} \mathrm{O}_{3}$, respectively. External ozone doses accumulated by the leaves are provided as AOT40 values $\left(\mathrm{nL} \mathrm{L}^{-1} \mathrm{~h}\right.$; see Materials and Methods). Data are presented as mean values $(n=5)$. Vertical bars represent standard errors (SE). Results of a one-way ANOVA: ***, $p<0.001$; **, $p<0.01$; *, $p<0.05$. When significance was accepted $(p<0.05)$, means were compared with a Newman-Keuls test: means identified with the same letter are not significantly different $(p>0.05)$.

that cells are richer in chloroplasts. It may basically be due to the unit in which pigment concentrations are expressed (mg $\mathrm{cm}^{-2}$ ) since that unit takes neither foliar dry matter nor leaf thickness into account. Indeed, it has been reported that leaf mass per unit leaf area (LMA) augments with leaf rank in maize plants (Drouet et al., 2005). Such an increase in LMA may result from an increase in leaf thickness (Maurice et al., 1997). Thus, the $10^{\text {th }}$ leaf appears richer in pigments than the $5^{\text {th }}$ leaf probably because it is thicker and therefore contains a much more important number of mesophyll cells.
Although they roughly experienced the same AOT40 doses in each of the two ozoneenriched atmospheres, $5^{\text {th }}$ and $10^{\text {th }}$ leaves exhibited distinct pigment responses to ozone. The decline in pigment content with increasing ozone concentration could be expected since it had been previously reported that ozone was able to accelerate leaf senescence by triggering an oxidative burst (Castagna et al., 2001; Calatayud and Barreno, 2004). If the deleterious ozone effect on photosynthetic pigments had been shown in many $\mathrm{C}_{3}$ species (Castagna et al., 2001; Calatayud and Barreno, 2004), no data were available in maize. Nevertheless, a 
$5^{\text {th }}$ leaf

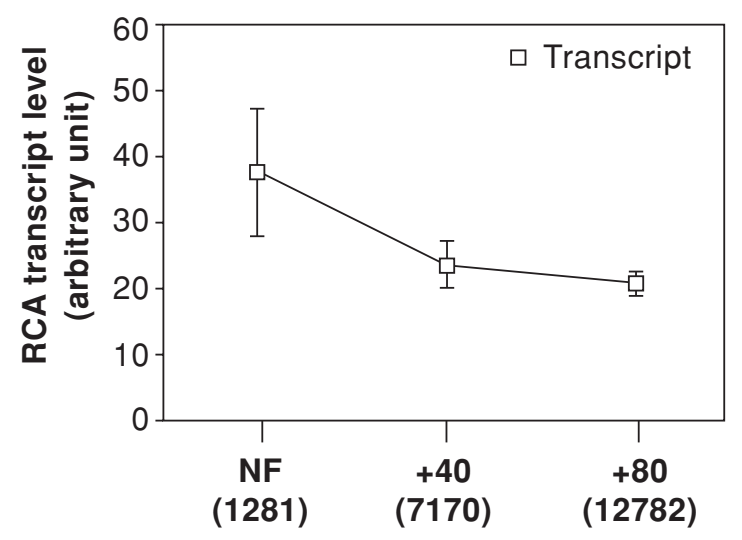

Atmosphere
(AOT40, nL L-1 h) 10th leaf

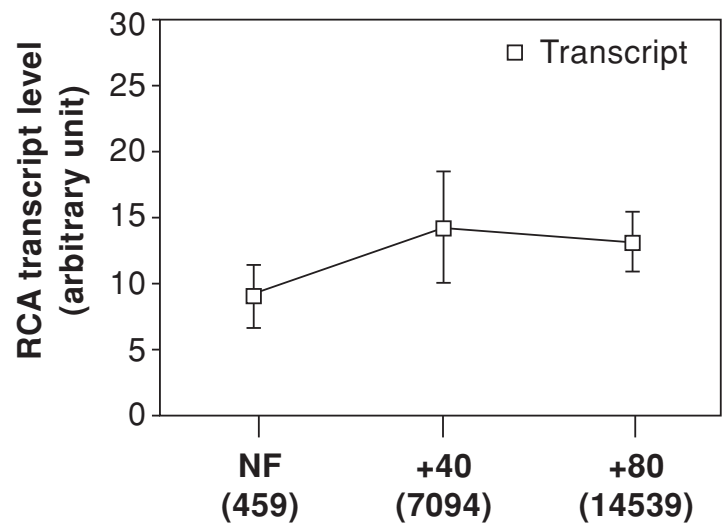

Atmosphere
(AOT40, nL L-1 h)

Figure 4: Rubisco activase transcript levels $\left(\square\right.$ determined in $5^{\text {th }}$ and $10^{\text {th }}$ leaves from maize plants exposed to three increasing $\mathrm{O}_{3}$ concentrations. Relative quantification of transcripts (arbitrary units) was performed by real-time RT-PCR with actin as housekeeping gene. NF, chambered non filtered air; $+40,+80$, chambered non-filtered air plus $40,80 \mathrm{~nL} \mathrm{~L}^{-1} \mathrm{O}_{3}$, respectively. External ozone doses accumulated by the leaves are provided as AOT40 values ( $\mathrm{nL} \mathrm{L}^{-1} \mathrm{~h}$; see Materials and Methods). Data are presented as mean values $(n=5)$. Vertical bars represent standard errors (SE). Results of a one-way ANOVA: ***, $p<0.001 ; * *, p<0.01 ; *, p<0.05$. When significance was accepted $(p<0.05)$, means were compared with a Newman-Keuls test: means identified with the same letter are not significantly different $(p>0.05)$.

decrease in maize chlorophyll content in response to different abiotic stresses (ultraviolet-B radiation or herbicide) known to generate AOS formation had been already reported (Jung, 2003; Correia et al., 2004). In our experiment, the loss in both chlorophylls (a and b) and carotenoids augmented across +40 and +80 atmosphere in the $5^{\text {th }}$ leaf while for the $10^{\text {th }}$ leaf, it occurred to a lesser extent only in +80 atmosphere. Thus, an AOT40 of $12782 \mathrm{~nL} \mathrm{~L}^{-}$ $1 \mathrm{~h}$ (accumulated in +80 atmosphere) reduced pigment content in the $5^{\text {th }}$ leaf drastically enough to be visible, whereas an almost similar AOT40 of $14539 \mathrm{~nL} \mathrm{~L}^{-1} \mathrm{~h}$ slightly depressed the pigment content of the $10^{\text {th }}$ leaf without modifying its visual aspect. The preferential degradation in $\mathrm{Chl}$ a that was noticed in both leaves from +80 atmosphere, relative to $\mathrm{Chl} \mathrm{b}$, was also expected since it had previously been reported in response to ozone, in $\mathrm{C}_{3}$ species (Castagna et al., 2001). If the effect of the reproductive growth on the profiles of maize leaf senescence was investigated with special regard to the node (Sadras et al., 2000), there are currently no clear data able to allow a comparison between senescence patterns of $5^{\text {th }}$ and $10^{\text {th }}$ leaves. Nonetheless, the distinct negative ozone impacts on pigmentation may be related to different physiological abilities. Indeed, the $10^{\text {th }}$ leaf that contributes to corn filling is characterized by a longer lifespan than the $5^{\text {th }}$ leaf that naturally begins to senesce earlier after its full leaf span. So, as compared to the $10^{\text {th }}$ leaf, a much more ozone-accelerated senescence in the $5^{\text {th }}$ leaf could be expected. The consistent increase in pigment content ( $\mathrm{Chl} \mathrm{a}, \mathrm{b}$ and $\mathrm{Car}$ ) that was observed in the $10^{\text {th }}$ leaf in response to a moderate addition of ozone ( +40 atmosphere) was more unexpected. Until now, only slight indications of a higher foliar chlorophyll concentration have been detected in potato and birch samplings 
grown under elevated $\mathrm{O}_{3}$ (Bindi et al., 2002; Karlsson et al., 2003). Comparatively, the pigment rise we evidenced (approximately $+33 \%$ ) is more spectacular and could be regarded as an adaptative response. By promoting light reactions of photosynthesis, it may contribute to enhance production of both ATP and reducing power required for detoxification and repaired processes. On the contrary, the ozone-induced pigment degradation can limit the ability of plants to use energy and consequently can contribute to the impairment of photosynthesis.

\section{mRNA levels and carboxylase protein accumulation}

With special regard to unstressed leaves from control treatment, we showed that carboxylase protein of the mature $5^{\text {th }}$ leaf (lower leaf) was roughly similar to that of the mature $10^{\text {th }}$ leaf (upper leaf). These relative amounts expressed as percentages of soluble proteins matched those already reported in maize (Sugiyama et al., 1984). The analysis of real-time RT-PCR data revealed that ozone was able to differentially disturb the amount of mRNAs encoding PEPc, Rubisco and Rubisco activase. Such ozone-induced changes in transcript levels did not necessarily reflect parallel changes in the protein products of these genes. Firstly, the transcript accumulation we measured must be regarded as a balance between transcription activity and mRNA stability that can be controlled in part, by further post-transcriptional events (DeRocher and Bohnert, 1993; Glick et al., 1995; Pell et al., 1997). Secondly, a tight linkage between mRNA quantity and the amount of its corresponding protein must not systematically be expected since (i) all transcripts are not necessarily translated and (ii) post-translational events as well as protein degradation also regulate protein accumulation (Moore et al., 1998; Suzuki et al., 2001; Cohen et al., 2005). On this subject, it is acknowledged that the expression of genes encoding Rubisco-SSU, Rubisco-LSU and PEPc may be regulated at transcriptional, translational and posttranslational levels (Eckardt and Pell, 1994; Glick et al., 1995; Pell et al., 1997; Moore et al., 1998; Suzuki et al., 2001; Cohen et al., 2005). Besides, ozone may differentially modify mRNA and protein accumulation.

\section{Ozone and PEPc}

PEPc is a cytosolic carboxylase made of four identical subunits of about $110 \mathrm{kDa}$ each (Nimmo, 2003). In $\mathrm{C}_{4}$ species such as corn, the photosynthetic isoform is responsible for primary $\mathrm{CO}_{2}$ fixation that characterizes $\mathrm{C}_{4}$ photosynthesis (Hudspeth and Grula, 1989). As for photosynthetic pigments, the highest ozone-enriched treatment $(+80)$ drastically reduced $\mathrm{C}_{4}$ PEPc transcripts in both sampled leaves whereas a moderate ozone addition (+40 treatment) corresponding to an external ozone dose of circa $7100 \mathrm{~nL} \mathrm{~L}^{-1} \mathrm{~h}$ could or could not decrease $\mathrm{C}_{4}$-PEPc mRNA accumulation in the $5^{\text {th }}$ and $10^{\text {th }}$ leaves, respectively. Variation patterns of PEPc protein content correlated roughly with mRNA data: changes followed the same direction, however, they did not have similar magnitudes. Light distortions in the correlation arose especially for +40 treatment. Indeed, in that atmosphere, the $10^{\text {th }}$ leaf $\mathrm{PEPc}$ protein content slightly increased $(+37 \%)$ whereas mRNA pool encoding $\mathrm{C}_{4}$-specific PEPc isoform remained stable. In the $5^{\text {th }}$ leaf from the same atmosphere, the PEPc protein content was slightly decreased whereas the $\mathrm{C}_{4}$ specific PEPc mRNA was severely decreased. Whatever the leaf, a much more important external ozone dose accumulated in +80 atmosphere (AOT40 of 12782 and $14539 \mathrm{~nL} \mathrm{~L}^{-1} \mathrm{~h}$ for $5^{\text {th }}$ and $10^{\text {th }}$ leaf, respectively) reduced both mRNA and protein suggesting that $\mathrm{O}_{3}$-derived AOS were produced in ample amounts to promote, via a transduction signal pathway, the deceleration of protein biosynthesis and probably an increase in protein degradation (Pell et al., 1997). In any case, we never detected an increase in PEPc protein or mRNA levels as previously reported for $\mathrm{C}_{3}$ species (Dizengremel, 2001). When it occurs, the loss in PEPc content might be partly the result of a biosynthesis inhibition at transcription level as suggested by the decrease in the corresponding transcripts. 


\section{Ozone, Rubisco and Rubisco activase}

Rubisco is a holoenzyme made of eight nucleus-encoded small subunits (SSU) and eight chloroplast-encoded large subunits (LSU). Its activity is partly regulated by another protein, Rubisco activase (Spreitzer, 1999). In control $5^{\text {th }}$ and $10^{\text {th }}$ leaves, the ratio of $\mathrm{RbcL}$ to $\mathrm{RbcS}$ mRNA was close to that $(10: 1)$ previously reported in maize leaves (Sheen and Bogorad, 1986). Whatever the atmosphere tested, this ratio remained roughly unchanged.

Surprisingly, ozone seemed to have no impact on Rubisco-related mRNAs from the $5^{\text {th }}$ leaf whereas in the $10^{\text {th }}$ leaf, contrary to what had been observed for PEPc mRNAs, ozone was able to slightly increase both LSU and SSU transcripts especially when it was added in moderate concentration $(+40)$. These data contrast with those from Ruzsa et al. (1999) who tested high ozone concentrations. Indeed, using Northern blot analysis, these authors showed that maize mRNA encoding Rubisco small subunit was decreased by (i) a single $6 \mathrm{~h}$ exposure to ozone concentrations ranging from 300 to $1000 \mathrm{~nL} \mathrm{~L}^{-1}$ and (ii) 3, 6, or 10 days of repeated exposure to ozone concentrations ranging from 100 to $300 \mathrm{~nL} \mathrm{~L}^{-1}$ (Ruzsa et al., 1999). These declines matched other results gained from various $\mathrm{C}_{3}$ plants. By means of Northern blot, it was shown that RbcS and RbcL transcripts were reduced in potato leaves exposed for 3 days to $80 \mathrm{~nL} \mathrm{~L}^{-1}$ ozone (Glick et al., 1995) whereas RbcS transcripts declined in Arabidopsis leaves exposed for 2 weeks to $150 \mathrm{~nL} \mathrm{~L}^{-1}$ ozone (Miller et al., 1999). Bahl and Kahl (1995) suggested that, in response to an air pollutant stress, transcription reduction of some lightregulated photosynthesis genes like $\mathrm{RbcS}$ could result from oxidative damages affecting photoreceptors and/or signal transduction molecules (Quail, 1991). As a confirmation, a blocked transcription of Rubisco-SSU gene has been already described in maize cells, upon photooxidation (Mayfield and Taylor, 1987). In the $5^{\text {th }}$ maize leaf, the absence of an ozone effect on Rubisco mRNA quantity could be connected with a probable age-related reduction in transcription activity as suggested by the amount of total RNA extracted from the control $5^{\text {th }}$ leaf that was about 2.8 times lesser than RNAs present in the control $10^{\text {th }}$ leaf (data not shown). Since it is admitted that synthesis of Rubisco declines once leaves are fully expanded (Dalling, 1987), Reddy et al. (1993) postulated that the impact of ozone on transcript level in mature leaves could not be as consistent as for the younger leaves. Still in the $5^{\text {th }}$ leaf, the ozone-induced variations in SSU and LSU protein amounts were almost similar to that observed for PEPc: no spectacular changes were detected for an AOT40 of $7170 \mathrm{~nL} \mathrm{~L}^{-1} \mathrm{~h}$ (+40 atmosphere) whereas a decline by a little less that one third was registered in response to an AOT40 of $12782 \mathrm{~nL} \mathrm{~L}^{-1} \mathrm{~h}$ (+80 atmosphere). In contrast to the results from Eckardt and Pell (1994) who found that LSU was less responsive to ozone than SSU but matching our previous results gained from bean (Junqua et al., 2000), we showed that both subunits of maize Rubisco were equally reduced by an appropriate ozone dose. Such similar reductions might reflect distinct ozone impact. Indeed, it has been postulated that the maintenance of subunit stoichiometries may be driven by two principal mechanisms: LSU would be preferentially adjusted at the level of RbcL mRNA translation initiation whereas SSU levels would be preferentially adjusted at the level of protein degradation (Rodermel, 1999). However, the decrease in Rubisco protein during natural senescence of leaves can also be accompanied by coordinated decreases in the levels of mRNAs for the small and large subunits of Rubisco (Jiang et al., 1993). In any case, the loss in Rubisco protein that has been extensively reported in $\mathrm{C}_{3}$ species exposed to ozone, is often regarded as a consequence of an enhancement in proteolysis activity related to an ozone-accelerated senescence process (Pell et al., 1994; Brendley and Pell, 1998; Junqua et al., 2000; Dizengremel, 2001). In our case, the idea that the reduction in Rubisco protein content is not due to a decline in transcription activity is corroborated by the study of the $10^{\text {th }}$ leaf from +80 atmosphere that also exhibited a slightly reduced Rubisco content together 
with a trend towards an increase in corresponding transcripts. Regarding photosynthetic genes including $\mathrm{RbcS}$, it has been previously reported that atmosphereinduced changes in the steady-state transcript levels do not necessarily reflect similar changes in the concentrations of corresponding proteins (Bahl and Kahl, 1995; Moore et al., 1998). Irrespective of a protein degradation acceleration, the absence of correlation between SSU and LSU transcript variations and their respective products could also be due to a possible oxidative alteration of the translation system, as already suggested by Reiss et al. (1983) in the case of a photooxidative stress. With regard to the $10^{\text {th }}$ leaf, the most original event was recorded in +40 atmosphere and consisted in the concomitant increase in both Rubisco subunit content (SSU and LSU) and their respective transcripts. To our knowledge it is the first time that such a phenomenon is observed in response to a moderate chronic ozone stress.

Until now, the effect of stresses on Rubisco activase has been poorly investigated (Portis, 2003). More precisely, to our knowledge, there are no data regarding the specific effect of ozone on Rubisco activase. Rubisco activase transcripts from the $5^{\text {th }}$ leaf tended to be less abundant in both ozone-enriched atmospheres related to the control, suggesting that Rubisco from ozonated $5^{\text {th }}$ leaf might be less activated. Conversely, the addition of either 40 or $80 \mathrm{~nL} \mathrm{~L}^{-1}$ supplemental ozone tended to promote the accumulation of Rubisco activase transcripts in the $10^{\text {th }}$ leaf. Even if measurements of steady-state mRNA content do not necessarily reflect the rate of translation or protein synthesis (Boschetti et al., 1990), our results suggest that ozone may either up- or down-regulate the carboxylation activity catalysed by Rubisco by modifying the quantity of the enzyme and/or by changing regulation of its activity.

To conclude, we showed that during its growing period a maize upper leaf such as the $10^{\text {th }}$ leaf is able to respond to a moderate external ozone dose (7094 $\left.\mathrm{nL} \mathrm{L}^{-1} \mathrm{~h}\right)$ by increasing photosynthetic pigments and transcripts encoding Rubisco and Rubisco activase. Level of $\mathrm{C}_{4}$-PEPc mRNA remained almost stable. Rubisco and PEPc protein amounts were not drastically changed, even if they tended to be increased. In response to a higher ozone dose (14539 $\left.\mathrm{nL} \mathrm{L}^{-1} \mathrm{~h}\right)$, pigments and transcripts encoding $\mathrm{C}_{4}$-PEPc were notably decreased. Conversely, levels of transcripts encoding both Rubisco subunits and Rubisco activase were not consistently disturbed even if they tended to be slightly augmented. Rubisco and PEPc protein amounts slightly declined. Regarding the $5^{\text {th }}$ leaf, the moderate external ozone dose $\left(7170 \mathrm{~nL} \mathrm{~L}^{-1} \mathrm{~h}\right)$ induced a loss in pigmentation, PEPc and Rubisco activase mRNAs. However, this moderate stress was unable to notably depress carboxylase protein amounts and mRNAs encoding Rubisco. Except for Rubisco mRNAs, all other measured parameters from the $5^{\text {th }}$ leaf were depressed by the highest ozone dose $\left(12782 \mathrm{~nL} \mathrm{~L}^{-1} \mathrm{~h}\right)$. Although the intensity of the measured ozone-induced variations might be affected by an open-top chamber effect, we showed that maize leaves can respond differentially to a similar ozone stress.

\section{ACKNOWLEDGEMENTS}

Louis Leitao is the recipient of a grant from the Région Aquitaine. This research programme is part of the multidisciplinary BioPollAtm project which is mainly funded by the Ministère de l'Ecologie et du Développement Durable (programme PRIMEQUAL 2), the Agence de l'Environnement et de la Maîtrise de l'Energie (Ademe), the Ministère Délégué à la Recherche (ACI Ecologie Quantitative, programme Biosphère Continentale) and the Institut National des Sciences de l'Univers / CNRS (Programme National de Chimie Atmosphérique). Additional financial support has come from the Région Aquitaine and the Conseil Général des Pyrénées-Atlantiques. We gratefully acknowledge Pr Eric Pinelli and Bertrand Pourrut for providing various facilities. We are thankful to Arnaud Verbaere for technical assistance. We also wish to thank Isabelle Langlois and the technical support 
of the Applied Biosystems company as well as the genomic platform of the Institut Fédératif de Recherche 31 (Institut Louis Bugnard, CHU Rangueil, 31432 Toulouse, Cedex 4) for providing excellent support during the setup of real-time PCR systems. We are indebted to Neau Eric for GeNorm analysis advice and to Arnaud Betbeder for English language improvement.

\section{REFERENCES}

BAHL A, KAHL G (1995) Air pollutant stress changes the steady state transcript level of three photosynthesis genes. Environ Pollut 88: 87-65

BINDI M, HACOUR A, VANDERMEIREN K, CRAIGON J, OJANPERA K, SELLDÉN G, HÖGY P, FINNAN J, FIBBI L (2002) Chlorophyll concentration of potatoes grown under elevated carbon dioxide and/or ozone concentrations. Eur J Agron 17: 319-335

BOSCHETTI A, BREIDENBACH E, BLATTLER R (1990) Control of protein formation in chloroplasts. Plant Sci 68: 131-149

BRADFORD MM (1976) A rapid and sensitive method for the quantitation of microgram quantities of protein utilizing the principle of protein-dye binding. Anal Biochem 72: 248-254

BRENDLEY BW, PELL EJ (1998) Ozone-induced changes in biosynthesis of Rubisco and associated compensation to stress in foliage of hybrid poplar. Tree Physiol 18: 81-90

BRUNNER AM, YAKOVLEV IA, STRAUSS SH (2004) Validating internal controls for quantitative plant gene expression studies. BMC Plant Biology 4: 1-7

CALATAYUD A, BARRENO E (2004) Response to ozone in two lettuce varieties on chlorophyll a fluorescence, photosynthetic pigments and lipid peroxidation. Plant Physiol Biochem 42: 549-555

CASTAGNA A, NALI C, CIOMPI S, LORENZINI G, SOLDATINI GF, RANIERI A (2001) Ozone exposure affects photosynthesis of pumpkin (Cucurbita pepo) plants. New Phytol 152: 223-229

CICERONE RJ (1987) Changes in stratospheric ozone. Science 237: $35-42$

COHEN I, KNOPF JA, IRIHIMOVITCH V, SHAPIRA M (2005) A proposed mechanism for the inhibitory effects of oxidative stress on Rubisco assembly and its subunit expression. Plant Physiol 137: 738-746

CORREIA CM, MOUNTINHO PERREIRA JM, COUNTINHO JF, BJÖRN LA, TORRES-PEREIRA JMG (2004) Ultraviolet-B radiation and nitrogen affect the photosynthesis of maize: a Mediterranean field study. Eur J Agron 22: 337-347

DALLING MJ (1987) Proteolytic enzymes and leaf senescence. In: (eds THOMPSON WW, NOTHNAGEL EA, HUFFAKER RC) Plant Senescence: its Biochemistry and Physiology. Rockville:American Society of Plant Physiologists. pp. 54-70

DEROCHER JE, BOHNERT HJ (1993) Development and environmental stress employ different mechanisms in the expression of a plant gene family. Plant Cell 5: 1611-1625

DIZENGREMEL P (2001) Effects of ozone on the carbon metabolism of forest trees. Plant Physiol Biochem 39: 729-742
DROUET J-L, PAGES L, SERRA V (2005) Dynamics of leaf mass per unit leaf area and root mass per unit root volume of young maize plants: implications for growth models. Eur J Agron 22: 185-193

ECKARDT NA, PELL EJ (1994) $\mathrm{O}_{3}$-induced degradation of Rubisco protein and loss of Rubisco mRNA in relation to leaf age in Solanum tuberosum L. New Phytol 127: 741-748

ECKARDT NA, PELL EJ (1995) Oxidative modification of rubisco from potato foliage in response to ozone. Plant Physiol Biochem 33: 273-282

FERRY G, TELLIER E, TRY A, GRES S, NAIME I, SIMON MF, RODRIGUEZ M, BOUCHER J, TACK I, GESTA S, CHOMARAT P, DIEU M, RAES M, GALIZZI JP, VALET P, BOUTIN JA, SAULNIERBLACHE JS (2003) Autotaxin is released from adipocytes, catalyzes lysophosphatidic acid synthesis, and activates preadipocyte proliferation. Up-regulated expression with adipocyte differentiation and obesity. J Biol Chem 278: 18162-18169

GLICK RE, SCHLAGNHAUFER CD, ARTECA RN, PELL EJ (1995) Ozone-induced ethylene emission accelerates the loss of ribulose-1,5-bisphosphate carboxylase/oxygenase and nuclear-encoded mRNAs in senescing potato leaves. Plant Physiol 109: 891-898

GRÜNHAGE L, JÄGER HJ, HAENEL HD, LÖPMEIER FJ, HANEWALD K (1999) The European critical levels for ozone: improving their usage. Environ Pollut 105: $163-173$

GUIDI L, DI CAGNO R, SOLDATINI GF (2000) Screening of bean cultivars for their response to ozone as evaluated by visible symptoms and leaf chlorophyll fluorescence. Environ Pollut 107: 349-355

HANHEN S, JOERIS T, KREUZALER F, PETERHÄNSEL C (2003) Quantification of photosynthetic gene expression in maize $\mathrm{C}_{3}$ and $\mathrm{C}_{4}$ tissues by real-time PCR. Photosynth Res 75: 183-192

HÄUSLER RE, HIRSCH HJ, KREUZALER F, PETERHÄNSEL C (2002) Overexpression of $\mathrm{C}_{4}$-cycle enzymes in transgenic $\mathrm{C}_{3}$ plants: a biotechnological approach to improve $\mathrm{C}_{3}$-photosynthesis. J Exp Bot 369: 591-607

HEAGLE AS, KRESS LW, TEMPLE PJ, KOHUT RJ, MILLER JE, HEGGESTAD HE (1988) Ozone doseyield response relationships. In: (eds HECK WW, TAYLOR OC, TINGEY DT) Assessment of Crop Loss from Air Pollutants. London, New York:Elsevier Applied Science. pp. 141-179

HEATH RL, TAYLOR TGE (1997) Physiological and plant responses to ozone exposure. In: (eds SANDERMANN H, WELLBURN AR, HEATH RL) Forest decline and ozone. Berlin: Springer-Verlag. pp. 317-398

HUDSPETH RL, GRULA JW (1989) Structure and expression of the maize gene encoding the phosphoenolpyruvate carboxylase isozyme involved in $\mathrm{C}_{4}$ photosynthesis. Plant Mol Biol 12: 578-589

JIANG CZ, RODERMEL SR, SHIBLES RM (1993) Photosynthesis, Rubisco activity and amount, and their regulation by transcription in senescing soybean leaves. Plant Physiol 101: 105-112

JUNG S (2003) Expression level of specific isozymes of maize catalase mutants influences other antioxidants on norflurazon-induced oxidative stress. Pest Biochem Physiol 75: 9-17

JUNQUA M, BIOLLEY JP, PIÉ S, KANOUN M, DURAN $\mathrm{R}$, GOULAS P (2000) In vivo occurrence of carbonyl residues in Phaseolus vulgaris proteins as a direct consequence of a chronic ozone stress. Plant Physiol Biochem 38: 853-861 
KANOUN M, GOULAS P, BASSERES A, BIOLLEY JP (2002) Ozone-induced oxidation of Rubisco: from an ELISA quantification of carbonyls to putative pathways leading to oxidizing mechanisms. Funct Plant Biol 29: 1357-1363

KARENLAMPI L, SKARBY L (1996) Critical Levels for Ozone in Europe: Testing and Finalizing the Concepts. University of Kuopio, Department of Ecology and Environmental Science, Kuopio

KARLSSON PE, UDDLING J, SKARBY L, WALLIN G, SELLDÉN G (2003) Impact of ozone on the growth of birch (Betula pendula) saplings. Environ Pollut 124: 485-495

KOLB TE, MATYSSEK R (2001) Limitations and perspectives about scaling ozone impact in trees. Environ Pollut 115: 373-393

LEITAO L, GOULAS P, BIOLLEY J-P (2003) Timecourse of Rubisco oxidation in beans (Phaseolus vulgaris L.) subjected to a long-term ozone stress. Plant Sci 165: 613-620

LICHTENTHALER HK (1987) Chlorophylls and carotenoids: Pigments of photosynthetic biomembranes. Method Enzymol 148: 350-382

MATILE P, HÖRTENSTEINER S, THOMAS H (1999) Chlorophyll degradation. Annu Rev Plant Physiol Plant Mol Biol 50: 67-95

MATYSSEK R, HAVRANEK WM, WIESER G, INNES JL (1997) Ozone and the forests in Austria and Switzerland. In: (eds SANDERMANN H, WELLBURN AL, HEATH RL) Forest Decline and Ozone. Berlin Heidelberg: Springer-Verlag. pp. 95-134

MAURICE I, GASTAL F, DURAND J-L (1997) Generation of form and associated mass deposition during leaf development in grasses: a kinematic approach for non-steady growth. Ann Bot London, 80: 673-683

MAYFIELD SP, TAYLOR WC (1987) Chloroplasts photooxidation inhibits the expression of a set of nuclear genes. Mol Gen Genet 242: 309-314

MILLER JD, ARTECA RN, PELL EJ (1999) Senescenceassociated gene expression during ozone-induced leaf senescence in Arabidopsis. Plant Physiol 120: 10151023

MILLER JE (1988) Effects on photosynthesis, carbon allocation and plant growth associated with air pollutant stress. In: (eds HECK WW, TAYLOR OC, TINGEY DT) Assessment of Crop Loss from Air Pollutants. London, New York:Elsevier Applied Science. pp. 287-314

MOORE BD, CHENG SH, RICE J, SEEMAN JR (1998) Sucrose cycling, Rubisco expression, and prediction of photosynthetic acclimation to elevated atmospheric $\mathrm{CO}_{2}$. Plant Cell Environ 21: 905-915

NIMMO HG (2003) Control of the phosphorylation of phosphoenolpyruvate carboxylase in higher plants. Arch Biochem Biophys 414: 189-196

PELL EJ, LANDRY LG, ECKARDT NA, GLICK RE (1994) Effects of gaseous air pollutants on ribulose bisphosphate carboxylase/oxygenase: effects and implications. In: (eds ALSHER RG, WELLBURN AR) Plant responses to the gaseous Environment: molecular, metabolic and physiological aspects. London:Chapman and Hall. pp. 239-253

PELL EJ, SCHLAGNHAUFER CD, ARTECA RN (1997) Ozone-induced oxidative stress: Mechanisms of action and reaction. Physiol Plantarum 100: 264-273

PELL EJ, SINN JP, BRENDLEY BW, SAMUELSON L, VINTEN-JOHANSEN C, TIEN M, SKILLMAN J
(1999) Differential reponse of four tree species to ozone-induced acceleration of foliar senescence. Plant Cell Environ 22: 779-790

PELLOUX J, JOLIVET Y, FONTAINE V, BANVOY J, DIZENGREMEL P (2001) Changes in Rubisco and Rubisco activase gene expression and polypeptide content in Pinus halepensis Mill. subjected to ozone and drought. Plant Cell Environ 24: 23-132

PFAFFL MW (2001) A new mathematical model for relative quantification in real-time RT-PCR. Nucleic Acids Research 29: 2002-2007

PORTIS AR (2003) Rubisco activase-Rubisco's catalytic chaperone. Photosynth Res 75: 11-27

QUAIL PH (1991) Phytochrome: a light-activated molecular switch that regulates plant gene expression. Annu Rev Genet 25: 389-409

REDDY CN, ARTECA RN, DAI YR, FLORES HE, NEGM FB, PELL EJ (1993) Changes in ethylene and polyamines in relation to mRNA levels of the large and small subunits of ribulose bisphosphate carboxylase/ oxygenase in ozone-stressed potato foliage. Plant Cell Environ 16: 819-826

REISS T, BERGFELD R, LINK G, THIEN W, MOHR H (1983) Photooxidative destruction of chloroplast and its consequences for cytosolic enzyme levels and plant development. Planta 15: 518-528

RODERMEL SR (1999) Subunit control of Rubisco synthesis- a relic of an endosymbiotic past? Photosynth Res 59: 105-123

RUZSA SM, MYLONA P, SCANDALIOS JG (1999) Differential response of antioxidant genes in maize leaves exposed to ozone. Redox Rep 4: 95-103

SADRAS VO, ECHARTE L, ANDRADE FH (2000) Profiles of leaf senescence during reproductive growth of sunflower and maize. Ann Bot London 85: 187-195

SHEEN JY, BOGORAD L (1986) Differential expression of six light-harvesting chlorophyll $\mathrm{a} / \mathrm{b}$ binding protein genes in maize leaf cell types. Proc Nat Acad Sci USA 83: 7811-7815

SOKAL RR, ROHLF FJ (2001) Biometry Third Edition. W. H. Freeman and Company, New York

SPREITZER RJ (1999) Questions about the complexity of chloroplast ribulose-1,5-bisphosphate carboxylase/ oxygenase. Photosynth Res 60: 29-42

SUGIYAMA T, MIZUNO M, HAYASHI M (1984) Partitioning of nitrogen among ribulose-1,5-bisphosphate carboxylase/oxygenase, phosphoenolpyruvate carboxylase, and pyruvate orthophosphate dikinase as related to biomass productivity in maize seedlings. Plant Physiol 75: 665-669

SUZUKI Y, MAKINO A, MAE T (2001) Changes in the turnover of Rubisco and levels of mRNAs of rbcL and $\mathrm{rbcS}$ in rice leaves from emergence to senescence. Plant Cell Environ 24: 1353-1360

THOMPSON AM (1992) The oxidising capacity of the earth's atmosphere: probable past and future changes. Science 256: 1157-1165

VANDESOMPELE J, DE PRETER K, PATTYN F, POPPE B, VAN ROY N, DE PAEPA A, SPELEMAN F (2002) Accurate normalization of real-time quantitative RTPCR data by geometric averaging of multiple internal control genes. Genome Biology 3: research 0034.10034.0011 http:/genomebiology.com/2002/3/7/ research/0034 (15-09-2007)

VON CAEMMERER S, FURBANK RT (2003) The $\mathrm{C}_{4}$ pathway: an efficient $\mathrm{CO}_{2}$ pump. Photosynth Res 77: 191-207

WALKER NJ (2002) A technique whose time has come. Science 296: 557-559 
